\title{
Knowledge, Perceptions and Attitudes on Education for Sustainable Development of Pre-Service Early Childhood Teachers in Greece
}

\author{
Anthoula Maidou ${ }^{1,}$, Katerina Plakitsi $^{1}$ \& Hariton M. Polatoglou ${ }^{2}$ \\ ${ }^{1}$ Department of Early Childhood Education, University of Ioannina, Ioannina, Greece \\ ${ }^{2}$ School of Physics, Aristotle University of Thessaloniki, Thessaloniki, Greece \\ *Correspondence: Department of Early Childhood Education, University of Ioannina, Greece. Tel: 30-694-848-7388. \\ E-mail: anthoula.maidou@gmail.com
}

Received: August 18, 2019

Accepted: September 27, 2019 Online Published: October 17, 2019

doi:10.5430/wje.v9n5p1

URL: https://doi.org/10.5430/wje.v9n5p1

\begin{abstract}
Education for Sustainable Development (ESD) is an important issue for the education of students worldwide because it offers knowledge, skills, attitudes and values necessary to ensure a sustainable future for humanity at local and global levels, which is nowadays becoming critical. The decade 2005-2014 called 'Decade of ESD' was an initiative by the United Nations to promote ESD worldwide, followed currently by the Agenda 2030. ESD should be an ongoing subject for students in formal and informal education, at all educational levels, and in life-long learning programs, starting with early childhood education. This paper reports on the knowledge, perceptions and attitudes of pre-service early childhood teachers of the University of Ioannina, Greece, on ESD using a quantitative approach utilizing a questionnaire. Our findings showed that most pre-service teachers had knowledge on environmental aspects but did not consider societal and financial matters to be aspects of ESD. Furthermore, most students had never ESD lessons during their formal education. Our findings depict that pre-service teachers believe that ESD is an important issue, that it should be included in the curricula and that lessons on EDS during their studies would develop their ability to teach ESD to their students.
\end{abstract}

Keywords: education for sustainable development, knowledge, perceptions, attitudes, teaching approaches of education for sustainable development

\section{Introduction}

\subsection{Education for Sustainable Development}

The World Commission on Environment and Development (WCED) held in 1983, resulted in the publication of a report named 'Our Common Future' or 'Brundtland report', where Sustainable Development (SD) was defined as: 'development that meets the needs of the present without compromising the ability of future generations to meet their own needs' (WCED, 1987, p43). This definition recognizes the importance of the environment as well as the needs for development for the society (McKeown \& Hopkins, 2003). Thus, the Brundtland report highlighted the three fundamental components of sustainable development, which are protection of the environment, while supporting economic growth and social equity and justice.

SD is difficult to define, because it is a complex notion still evolving (McKeown, 2002), the descriptions of ESD are still blurred and the definition of EDS from 'Our common future' depends on the reader as the definition can be understood in many ways (Bursjöö, 2011; O’Riordan \& Voisey, 1998; Fien \& Tilbury, 2002). This abundance of views leads to different notions and pedagogy of ESD (Scott, 2005; Scott \& Gough, 2003), while some scholars believe that there is not one 'correct' conception of SD (Cotton, Warren, Maiboroda \& Bailey, 2007).

The importance of ESD has been recognized by bodies like UNESCO $(2002,2004)$, which took a leading role in promoting ESD (UNESCO, 2009, 2012). UNESCO established the decade 2005-2014 as the Decade of ESD, envisioning a world where everyone had the opportunity to benefit from education and acquire the values, behaviors and lifestyles necessary for a sustainable future and positive social transformations (UNESCO, 2004, p. 4). Education was considered a priority for the Strategy for ESD (UNECE, 2005), because it can develop and strengthen 
knowledge, skills and values and empower people of all ages to take actions for a sustainable future. Mogensen and Schnack (2010) ascribe the challenge for ESD in identifying the kind of learning that motivates the learners to become active citizens in a complex and uncertain reality, promoting a democratic citizenship, working with conflicting interests and critical thinking, argumentation and alternative actions.

Although efforts to introduce ESD in the educational practice worldwide started systematically with the Decade for ESD in 2004 on a global level, it is still not a common practice in many curricula worldwide. The complex and manifold subject and furthermore its interdisciplinary character are a true challenge for many educators. Furthermore, as McKeown (2014) puts it 'Reorienting education to address sustainability is a deep process that involves changes in programmes, practices, and policy, as well as awareness, knowledge, skills and values and acceptance of the sustainability paradigm. The reorienting process is a reflective process that takes time, intentionality and effort to accomplish. Reorienting teacher education typically takes years of work in teacher education institutions to create deep and enduring changes'.

To be able to include ESD in their teachings, educators must have knowledge of the subjects that establish ESD and positive attitudes towards it, as well be aware of the appropriate teaching approaches when addressing ESD issues in the classroom.

\subsection{Knowledge of Sustainable Development Issues}

For teachers to be able to teach their students about SD, they need to be environmentally knowledgeable (Tuncer et al., 2009), because lack of knowledge is a significant inhibiting factor (Hart \& Nolan 1999).

The environment, the society and the economy are interrelated, therefore social or economic decisions may cause environmental problems. Furthermore, to fulfill the social and economic needs development is needed to promote environmental conservation. Adawiah \& Norizan (2012) found that in-service teachers have a good overall knowledge about the three components of ESD but lack the understanding of their interrelatedness, while Borg, Gericke, Höglund and Bergman (2014) observed that teachers are aware of the relevance of the three dimensions of ESD to various degrees, but do not generally have a holistic understanding. Similar results were reported by several studies showing that most teachers do not have a holistic understanding of the SD concepts (Jucker, 2002; Summers $\&$ Childs, 2007) and that the ecological perspective is the most commonly recognized (Corney, 2006; Cotton et al. 2007; Pepper \& Wildy, 2008; Summers, Childs, \& Corney, 2005; Summers, Corney, \& Childs 2004).

Although according to some studies teachers' conceptual understanding varies greatly and that those who have a good knowledge often lack to realize the interrelatedness of the SD components, many studies still point out the deficiency of appropriate training during their studies which results in poor knowledge of sustainability issues (Cordina \& Mifsud, 2016; Cutter-Mackenzie \& Smith, 2003; Symons, 2008; Yavetz, Goldman \& Pe'er, 2009), hindering significantly the implementation of ESD in the classroom.

Kennelly, Taylor, and Maxwell (2008b) found that pre-service teachers' confidence to teach about sustainability issues increased after participation in an ESD course during their teacher education program, which resulted in improved knowledge of the environment. While many researchers argue that knowledge and understanding of sustainability may not necessarily lead teachers to action, or to effectively teaching about ESD issues (Cutter-Mackenzie \& Smith 2003; Kennelly, Taylor, \& Maxwell 2008a; Stevenson 2007), it has been suggested that knowledge of sustainability issues in combination with the necessary pedagogical skills, values and attitudes might support teachers' confidence and readiness to implement ESD in the classrooms (Symons 2008).

\subsection{Perceptions about Education for Sustainable Development}

People operate by developing personal constructs which enable them to interact with and interpret the world about them (Green, 2004; Shapiro, 1991). Cognitive, social and personal factors influence these personal constructs, which are continuously revised as a result of new experiences. The terms constructs, beliefs and values are often used interchangeably by those involved in education (Horley, 1991), while also many scholars refer to them as views or perceptions. Beliefs are often considered to be shared interpretations (Dillon \& Gayford, 1997), and in this way the term belief is used as a social construct.

Corney and Reid (2007) attribute the ability and capacity of teachers to address sustainability at schools on teachers' knowledge and beliefs about subject matter and pedagogy. Bandura $(1977,2005)$ describes self-efficacy as concerned with people's beliefs in their capabilities to produce certain attainments, and that efficacy as a belief system is not a global trait, but a differentiated set of self-beliefs linked to distinct realms of functioning (Bandura, 2005). Self-efficacy can thus be used to predict behaviors (Tschannen-Moran, Hoy, \& Hoy, 1998; Gan \& Gal, 2018). Teachers perceptions of their own understanding of ESD aspects, as well as how they perceive their ability to teach 
these subjects are important (Borg, Gericke, Höglund \& Bergman, 2014; Gan \& Gal, 2018; Malandrakis, 2018).

\subsection{Teachers Attitudes towards Education for Sustainable Development}

Many researchers argue that knowledge and understanding of sustainability may not necessarily lead to a responsible behavior, nor to effective teaching of ESD in classrooms (Cutter-Mackenzie \& Smith, 2003; Cutter-Mackenzie \& Tidbury, 2002; Gayford \& Dillon, 1995; Kennelly, Taylor, \& Maxwell, 2008a; Stevenson, 2007). Nevertheless, it has been suggested that a wide-ranging knowledge of sustainability issues - in addition to the necessary pedagogical skills, values and attitudes - might enhance teachers' confidence and readiness to teach ESD in schools (Symons 2008). Karpudewan, Ismail, and Roth (2012) suggest that assisting future teachers in changing their attitudes might lead to greater impacts of attitude change once they are in the classroom influencing their students.

Many researchers emphasize the importance of attitudes for teaching about ESD (Biasutti \& Frata, 2017; Cordina \& Mifsud, 2016; Shephard, 2008). Developing a positive attitude towards sustainability by educating pre-service teachers might promote engagement with ESD (Tomas, Girgenti \& Jackson 2017). Furthermore, research related to ESD shows that school education consists of fact-based knowledge as well as moral and value-based issues (Jensen \& Schnack, 1997) and that this teaching also deals with attitudes, reasoning and lifestyle issues (Bursjöö, 2011; Sund \& Wickman, 2007). Gan and Gal (2018) found that a pre-service teacher with a high level of self-efficacy for promoting ESD exhibited positive attitudes towards the environment and pro-environmental behaviors in the private and public spheres.

A positive attitude towards ESD principles was also discovered by Chunteng (2004) when surveying primary and secondary school teachers' teaching competences for EE. Despite this, Chunteng argued that these attitudes were affected negatively by the participants' lack of knowledge and awareness.

\subsection{Appropriate Teaching Approaches for ESD}

In the 2030 Incheon Declaration (UNESCO 2016) participants stated that their vision is to transform lives through education, recognizing the important role of education as a main driver of development and in achieving the other proposed Sustainable Development Goals. Furthermore, they committed '...We reaffirm that education is a public good, a fundamental human right and a basis for guaranteeing the realization of other rights. It is essential for peace, tolerance, human fulfilment and sustainable development. ...'. Education was always considered a fundamental component of ESD by UNESCO and is a core aspect of Agenda 21 (UNESCO 1992) thus '... education is considered crucial for supporting sustainable development and for advancing the ability of the people to address sustainable development issues.'

Furthermore, teachers' perceptions on the importance of ESD for their teaching plays also a major role for their attitude towards ESD and their willingness to learn about the subject. Participatory approaches can bee seen as tools for developing and sharing knowledge, skills, and experiences that lead to cognitive gains, action competence, and community building (Hart, 2008; Læssøe, 2008; Dyment, 2008; Schusler \& Krasny, 2008). Furthermore, participatory approaches can be used to co-determine educational processes and outcomes through interaction of teachers and learners in planning their learning processes (Schnack, 2008). Participatory approaches offer participants various opportunities to exercise their democratic rights to participate in civil society, and in decision-making and actions that promote justice, equality, and well-being for all (Reid, Jensen, Nikel, \& Simovska, 2008). Engagement in the teaching units was also considered important by Tomas, Girgenti and Jackson (2017).

Teachers need to have subject and pedagogical knowledge to be able to teach about ESD (Summers, Corney, \& Childs, 2003). Scholars agree that the preferred teaching approaches to ESD should be student-centered (McNaughton 2012; Tomas, Girgenti, \& Jackson, 2017; UNESCO, 1992) experiential, participatory (Lysgaard \& Simovska, 2016), praxis-orientated, place-based, interdisciplinary (UNESCO, 1992; Saka \& Sahintürk, 2013), inquiry-based and transformational (Biasutti, 2015; Biasutti \& Frate, 2017; Christie et al., 2013; Corney \& Reid, 2007; Cotton et al., 2009; Tomas, Girgenti, \& Jackson, 2017; Wals \& Jickling, 2002). These teaching/learning methods promote changes in behaviors and ways of thinking and relate not only to knowledge but also to processes, because these methods teach learners how to think (Biasutti, 2015). These pedagogies are student-centered, and apply teaching approaches as fieldwork, role plays, debates, reflective accounts, case studies, and critical reading and writing activities enquiry-based learning, experiential learning and action competence (Christie, Miller, Cooke, \& White, 2013; Cotton \& Winter, 2010; Garrard, 2010; Jucker, 2002; Sterling, 2010; UNESCO, 2012;). ESD promotes competencies like critical thinking, imagining future scenarios and making decisions in a collaborative way. Therefore, ESD requires far-reaching changes in the way education is often practiced today (UNESCO, 1992).

Because of the importance of sustainability pedagogies in the teaching practice, it is necessary to reorient teacher 
education towards sustainability (UNESCO, 2004, 2005) and adapt more systemic and transdisciplinary models of teaching and learning in higher education (Sterling, 2010), and, specifically, in teacher education (Firth \& Winter, 2007; Hopkins \& McKeown, 2005; Summers, Childs \& Corney, 2005). These approaches differ from the usual way of teaching and learning in higher education (Sterling, 2012). University teachers become increasingly motivated to include more student-centered approaches in order to include sustainability issues and appropriate approaches in their practice (Christie et al., 2013; Cotton et al., 2009; Tomas, Girgenti, \& Jackson, 2017).

\subsection{Our Contribution}

Although ESD should be an ongoing topic for students of all educational levels (UNESCO, 2005b), pupils come first in contact with these issues during early childhood education (e.g. Caiman \& Lundegård, 2014; Duhn, 2012; Prince, 2010). Teachers of all educational levels should be aware of the importance of ESD and be able to include environmental issues in all subjects (Plakitsi et al., 2013). Especially early childhood educators and primary school teachers should be able to teach and make the youngest pupils aware of the importance of having sustainable environmental knowledge and a positive attitude towards the preservation of our planet (Roth, Goulat, \& Plakitsi, 2013).

To inquire about pre-service teachers' ability and willingness to include SD issues in their teachings we conducted survey. The research questions were:

1. What are pre-service teachers' levels of understandings/knowledge of SD?

2. How do they view ESD?

3. What are teachers' attitudes towards ESD?

4. What skills and teaching styles do they feel being appropriate to utilize in teaching ESD?

\section{Method}

Teachers' knowledge, views and attitudes towards ESD are important, since their teaching depends strongly on them (Haney, Lumpe, Czerniak, \& Egan, 2002; Milner, Sondergerd, Demir, Johnson, \& Czerniak, 2012). To inquire about the pre-service Early Childhood teacher's knowledge, beliefs and attituds towards ESD we used a questionnaire. We wanted to gain an insight on the abilities and willingness of the pre-service teachers of our university to include ESD aspects in their teaching.

\subsection{The Sample}

192 students of the Early Childhood Education Department of the University of Ioannina answered the questionnaire, of which 8 (4.2\%) male, $184(95.8 \%)$ female, mainly belonging to the age group 20-24 (93.8\%), as depicted in Table 1. The sample is considered representational of the pre-service teachers in Greece, since our students stem from various parts of Greece.

Table 1. Age Groups of the Participants.

\begin{tabular}{ccc}
\hline Age group & Count N & Percentage \\
\hline under 20 & 8 & $4.2 \%$ \\
$20-24$ & 180 & $93.8 \%$ \\
$25-29$ & 1 & $0.5 \%$ \\
$30-34$ & 2 & $1.0 \%$ \\
$35-40$ & 0 & $0.0 \%$ \\
over 40 & 1 & $0.5 \%$ \\
\hline
\end{tabular}

Most of the participants were full time students $(98,4 \%)$ and only 3 people were in-service teachers going for a second degree in Early Childhood Education. 2.1 Identify Subsections.

\subsection{The Questionnaire}

This study was a result of our stance that ESD should be taught in all educational levels starting from early childhood education. To get an insight on the knowledge, views and attitudes of pre-service teachers since all these aspects influence their teaching practice (Milner, Sondergerd, Demir, Johnson, \& Czerniak, 2012), we used a questionnaire with closed ended questions.

The questionnaire was completed on-line, anonymously. Students were invited through the closed laboratory's 
Facebook account to complete the questionnaire.

The questionnaire is based on the questionnaire of Cotton and coworkers (2007), which was created to explore the knowledge, beliefs and attitudes of university teachers on SD issues. Cotton et al. (2007) had developed a questionnaire that was appropriate to answer our research questions on knowledge, perceptions and attitudes towards ESD issues and was tested and evaluated. It was furthermore also used by another research team (Borg, Gericke, Höglund \& Bergman, 2014) with similar questions to identify the knowledge, perceptions and attitudes towards SD of secondary school teachers. We did not use all the questions of Cotton's and coworkers (2007) questionnaire because SD was only a part of our own questionnaire. We furthermore added 3 questions one on the definition of SD and 2 on key issues of SD as reported by UNESCO (2005). In addition, we added a few questions from the questionnaire of Tomas, Girgenti and Jackson (2017) applied in their research on students' attitudes towards ESD.

The questions covered the following groups:

1. Knowledge of different aspects of ESD

2. Views of students on ESD

3. Attitudes of students towards EDS

4. Teaching approaches, they consider suitable for teaching ESD

The quantitative data were analysed using SPSS (Statistical Package for Social Sciences), version 22. The questionnaire was applied during the academic year 2017-2018.

\section{Results}

\subsection{Knowledge of Sustainable Development}

When asked if environmental issues are a concern of SD, almost all student teachers agreed, about the half of them acknowleged societal issues as a matter for SD, while only about one third agreed about financial matters, as depicted more precisely in Table 2 .

Table 2. Responses about the Dimensions of ESD

\begin{tabular}{lll}
\hline Aspects & $\mathrm{N}$ & $\%$ \\
\hline Environmental & 183 & $95,8 \%$ \\
Societal & 95 & $49,7 \%$ \\
Financial & 66 & $34,6 \%$ \\
Other & 11 & $5,8 \%$ \\
\hline
\end{tabular}

In order to understand the ways respondents interpreted the concept of sustainable development, they were asked to indicate their views on a series of propositions using five-point Likert scales (Table 3). The statements which received the strongest agreement (counting the percentage of strongly agree and Agree) as a key part of sustainable development were Items 7, 2, 4 and 1 in Table 3, all reflect an environmental view of sustainable development. Questions about societal or economic issues got less support. The statements which received the least agreement (Items 9 and 6) reflect societal and economic issues. Items 6 and 10 received the highest 'neutral' responses, suggesting that the pre-service teachers were rather uncertain if these items are issues of sustainable development. Although, when explicitly asked if societal aspects are subjects for ESD, the social dimention was acknowledged only by about half of the pre-service teachers, when asked to comment about specific statements, while all environmental aspects got the most "strongly agree" and "agree" mentions, as shown in Table 3, supprisingly the statement Social progress that recognizes the needs of everyone scored very close to the environmental statements, while the question about gender equality scored very low (20.6\% strondly agree and agree), which is even lower than the statements about financial aspects. Furthermore, items 7 and 9 fall actually in all three SD dimentions, the first one, namely Acting now which is expensive but provides opportunities for a good life quality for future generations, got the most 'strongly agree' and 'agree' selections, and therefore was probably considered by the pre-service teachers as an environmental issue, while the second one, Sustainable urbanization, was considered very low with a high neutral statement, reflecting their uncertainty. 
Table 3. Views on Key Elements of SD (Percent).

\begin{tabular}{llllll}
\hline $\begin{array}{l}\text { To what extent do you consider that each of the following } \\
\text { is implied by the term "sustainable development"? }\end{array}$ & $\begin{array}{l}\text { Strongly } \\
\text { Agree }\end{array}$ & Agree & Neutral & Disagree & $\begin{array}{l}\text { Strongly } \\
\text { Disagree }\end{array}$ \\
\hline Maintaining biodiversity & 14,7 & 40,5 & 37,9 & 5,8 & 1,1 \\
Recycling waste products & 26,2 & 38,2 & 31,4 & 3,7 & 0,5 \\
Helping people to avoid starvation and disease & 9,4 & 35,1 & 39,8 & 13,1 & 2,6 \\
$\begin{array}{l}\text { Exploiting natural resources while maintaining critical } \\
\text { natural capital }\end{array}$ & 18,5 & 37,0 & 38,1 & 5,3 & 1,1 \\
Having significant local production and consumption & 13,3 & 29,8 & 42,6 & 13,8 & 0,5 \\
Maintaining economic growth & 9,0 & 26,1 & 47,9 & 16,0 & 1,1 \\
Acting now which is expensive but provides opportunities & 30,1 & 39,2 & 26,3 & 4,3 & 0 \\
for a good life quality for future generations & & & & & \\
Social progress recognizing the needs of everyone & 9,6 & 40,1 & 38,5 & 9,6 & 2,1 \\
Gender equality & 5,8 & 14,8 & 38,1 & 25,9 & 15,3 \\
Sustainable urbanization & 11,8 & 29,9 & 46,5 & 9,1 & 2,7 \\
\hline
\end{tabular}

\subsection{Perceptions of Pre-service Teachers about Education for Sustainable Development}

The outcome of the questionnaire showed that very few pre-service teachers rated their knowledge of SD as very good $(1.6 \%)$ and good $(13.0 \%)$, while $27.1 \%$ consider their knowledge low and $11.5 \%$ insufficient, leaving about half of them (46.9\%) rating their knowledge as moderate. $63.7 \%$ of the participants had never lessons on EE or ESD during their formal studies. When asked if they feel they need further training on ESD the vast majority agreed strongly (32.5\%) and agreed (46.1\%), while only $2.6 \%$ disagreed and $2.1 \%$ disagreed strongly. They also believe that including ESD in their curricula could improve their ability to teach their students (30.9\% agree strongly and $41.9 \%$ agree, while $23 \%$ feel neutral about it), and furthermore, they stated to a high percentage that university departments which prepare teachers of any level should include ESD training (35.3 agree strongly and 41.6 agree), while only about $4 \%$ disagree. They also stated that they believe that teachers can contribute to solve environmental problems through their teaching $30.9 \%$ agree strongly and $39,3 \%$ agree, while only about $2 \%$ disagree and strongly disagree in total.

\subsection{Attitudes towards Education for Sustainable Development}

When asked how they view SD most answered, I think it is a Good Thing $(69,8 \%)$ and only $12.2 \%$ stated that they are passionate advocates. It is though interesting that about $11.64 \%$ mentioned that they don't really know what SD is about, as can be noticed in Figure 1.

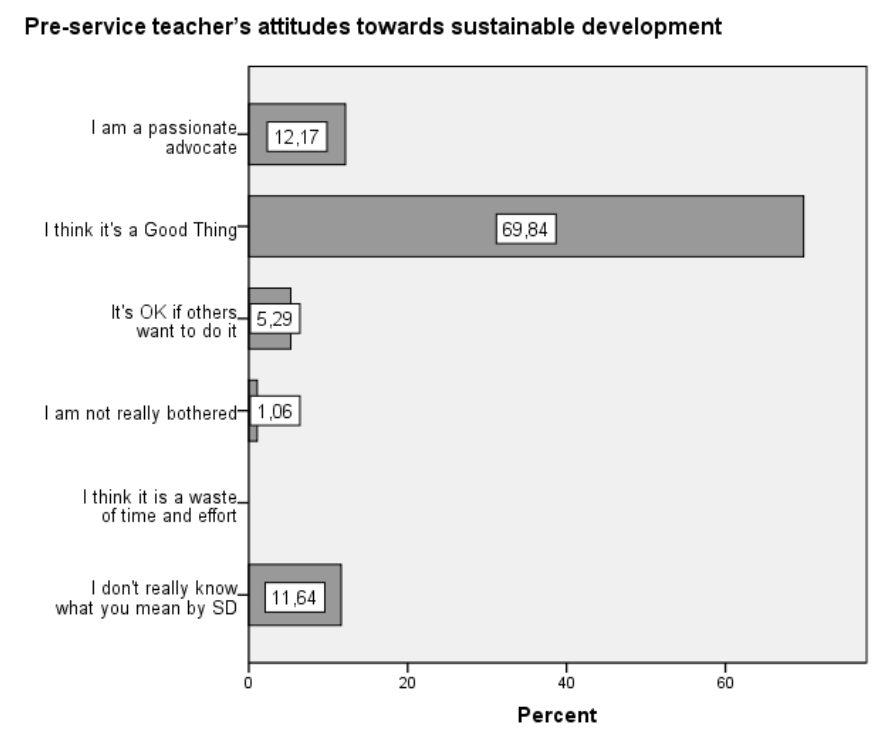

Figure 1. Pre-Service Teachers' Attitudes Towards SD 
Most of the pre-service teachers concider that sustainable development issues are important for their teachings and their personal stance altogether $(89.78 \%)$, while very few for their own particular teaching interests $(4.84 \%)$, or for their personal stance $(3.76 \%)$, and astoundingly $1.61 \%$ concider them not important.

Furthermore, most of the pre-service teachers state that they will include ESD in their teaching (picture 2). They also disagree to a high percentage (28,3 disagree and 38,2 disagree strongly) that ESD is a trend that will soon pass.

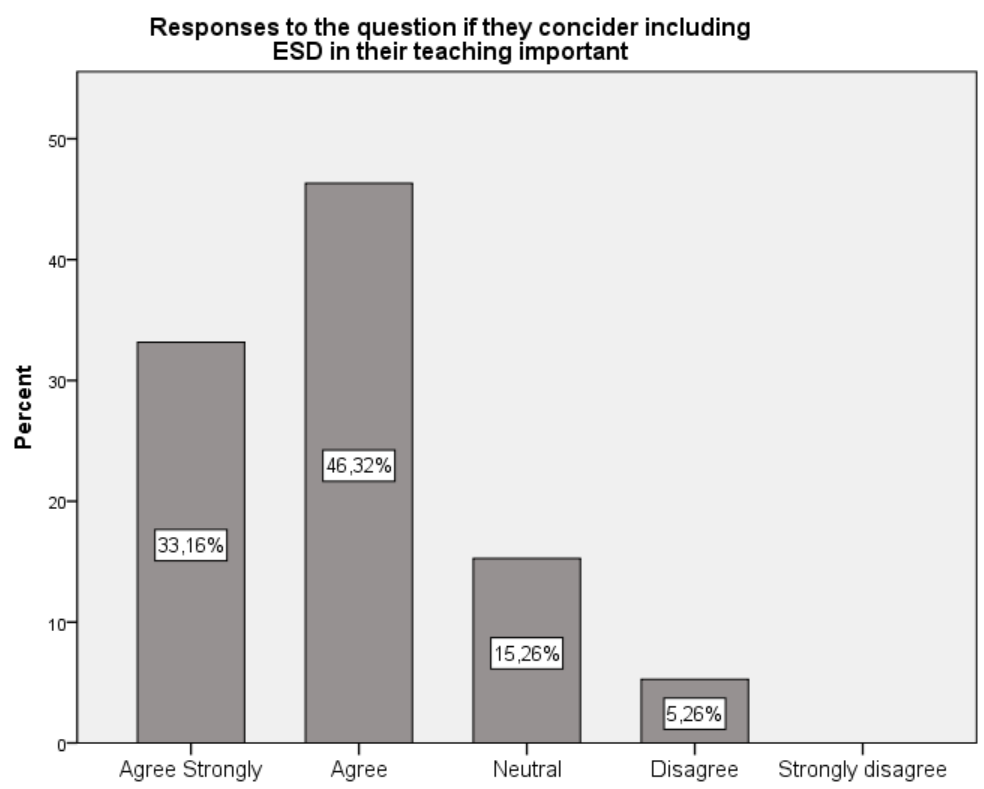

Figure 2. Responses to the Question if Pre-Service Teachers Consider Including ESD in Their Teaching Important

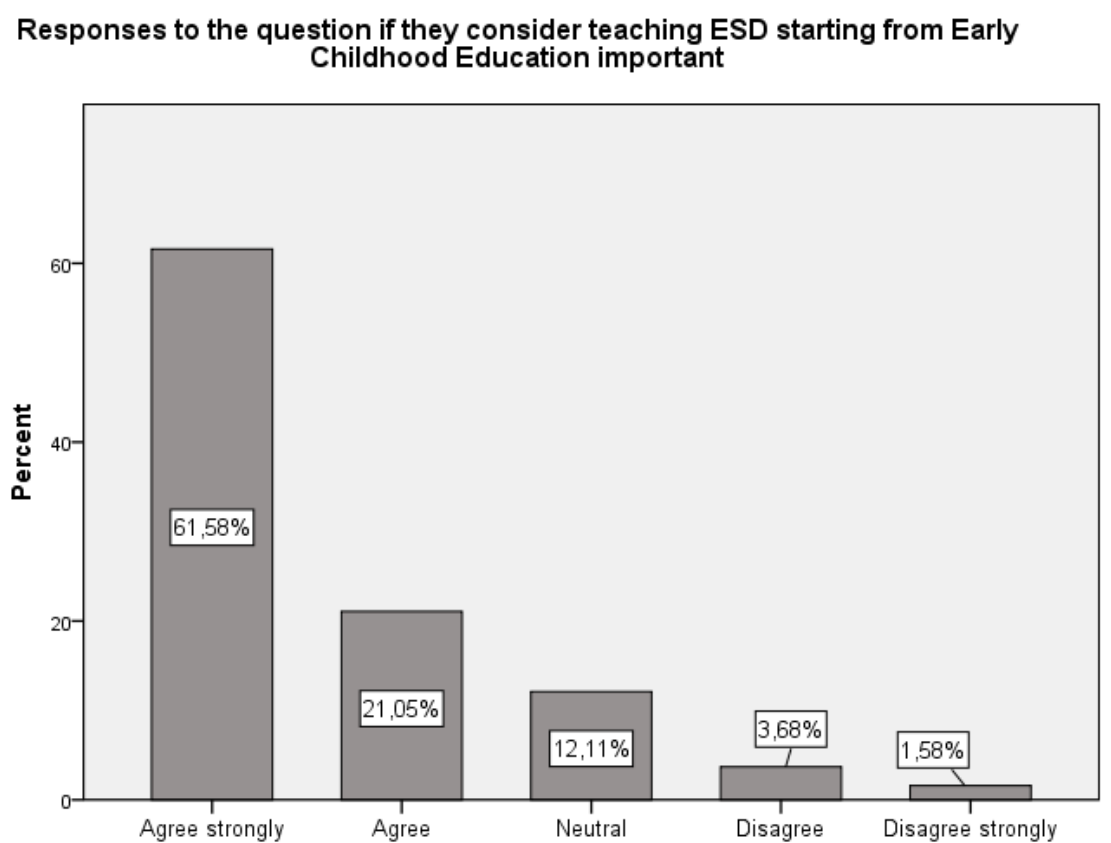

Figure 3. Answers to the Questions if Pre-Service Teachers Find It Important to Start Teaching ESD Starting from Early Childhood Education 
Furthermore, $30.9 \%$ agree strongly and $41.9 \%$ agree that incorporating ESD into the curricula will directly impact their ability to teach about sustainability to their students. When asked if they do you believe it is important to teach about the environment starting at Early Childhood education the majority agreed strongly or agreed as presented in Figure 3.

To the question 'Do you believe you need more education on SD issues', most students responded Much (46.1\%) and Very Much (32.5\%) - 16.1\% stated Neutral and only 2.6\% answered Little or 2.1\% None. The clear majority of the pre-service teachers believe thus that they need more education of SD.

\subsection{Appropriate Teaching Approaches for Education for Sustainable Development}

Most pre-service teachers are aware that ESD needs specific teaching approaches (78.61\%), while $17.62 \%$ do not support this statement, and $3.74 \%$ express an unwillingness to include ESD in their teachings.

They were also asked about the teaching approaches they find most appropriate when teaching their students on ESD. The answers are presented in Table 4. Most pre-service teachers prefer interactive, hands-on teaching approaches, as Excursion, Group Discussions/Work, Site Visit. Less preferred were Guided independent study, Debates, Interdisciplinary work, and Lectures. Guest Speakers and Case Studies are also low in their preferred teaching approaches, while Role Playing, Interactive Lectures, and small Group Research Projects are inbetween. It is somehow surprising to find interdisciplinary work among the less preferred teaching approached. This might be due to a misinterpretation of the approach or that their approach is always interdisciplinary.

Table 4. Major Teaching Approaches Considered Appropriate by the Pre-Service Students

\begin{tabular}{lc}
\hline Teaching approach & Percent \\
\hline Case Study & 35,3 \\
Excursion & 88,3 \\
Interactive lecture & 53,1 \\
Guest speakers & 33,3 \\
Group discussions/work & 75,4 \\
Lectures & 21,4 \\
Debates & 12,0 \\
Interdisciplinary work & 18,2 \\
Guided independent study & 11,8 \\
Role-playing & 51,9 \\
Small-group research projects & 56,7 \\
Site visit & 74,9 \\
\hline
\end{tabular}

\section{Discussion}

\subsection{Dimensions of Sustainable Development}

The findings indicate that pre-service teachers have the understanding that the environment is a major problem but are unaware that it is connected with societal and economic problems, replicating a former research on geography and science pre-service teachers by Summers, Corney and Childs (2004) who found that pre-service teachers also perceived environmental factors to be more relevant $(87 \%)$, then economic $(69 \%)$ and social $(49 \%)$ factors. The ecological dimension was also predominant in relavant studies about university teachers (Cotton et al., 2007; Reid \& Petocz, 2006; Summers \& Childs, 2007), as well as in an inquiry about the conceptual understanding of in-service teachers (Borg et al., 2014). An overrating of the environmental dimention could be due to the connection many make of ESD to environmental education (Bonnett, 2003; Winter \& Firth, 2007).

The societal dimension was considered by approximately the half of the pre-service teachers of our study, reflecting similar findings for in-service teachers of the study of Borg and coworkers (2014). This might be due to the vaguely defined notion of the societal dimesion. Many scholars agree that although the concept of SD refers in general to a balance between the environmental, economic, and societal dimensions of sustainability, the meaning of the societal component remains unclear (Boström, 2015; Casula Vifell \& Soneryd, 2012; Colantonio \& Dixon, 2009; Cuthill, 2010; Dempsey et al., 2011). This uncertainty is also reflected in the issues covered by the societal dimention, which might explain the low comprehension of the pre-service teachers of our study, thus, explaining the so differently perceived statements of Social progress that recognizes the needs of everyone and gender equality. The first statement about Social progress can be seen as a very positive statement, since it refers to the recognition of the 
needs of everyone, and thus might have received so many agreements. The second statement about gender equality was surprisingly considered not as an issue of ESD although gender equality is a prerequisite for sustainable development, because there are dissimilarities in the lifestyles and consumption patterns of women and men, as for example in their environmental impact, as stated by Johnsson-Latham (2007) describing how men, primarily through their greater mobility and more extensive travel, account for more carbon dioxide $\left(\mathrm{CO}_{2}\right)$ emissions than women, in both rich and poor countries. Or more generally expressed by the UN: "While the world has achieved progress towards gender equality and women's empowerment under the Millennium Development Goals (including equal access to primary education between girls and boys), women and girls continue to suffer discrimination and violence in every part of the world' (United Nations, 2019). The underration of our students of gender equality as an aspect considered for ESD could either be due to the impression especially shared by man, that in our country women are treated equally, or that it is not a very critical matter, which surely needs further investigation.

The economic dimension of SD, only acknowledged by approximately one third of the participating pre-service teachers, is also characterized by Borg and coworkers (2014) as the dimension associated with the greatest uncertainty, because it exhibited the greatest variation in teachers' conceptual understanding in their study. Although UNESCO (2005), supports the idea that economic growth should be integrated into the concept of SD, recent findings show that this is not necessary, because economic growth has both negative and positive effects (Haapanen \& Tapio, 2016) and therefore, economic growth should not be examined as a whole. Haapanen and Tapio found that the $21^{\text {st }}$ century growth critique does neither support continual downsizing of the economy nor condemn all growth, but instead they suggest selectively promoting actions that have positive effects on the environment and/or human well-being. They furthermore continue stating that 'If we are able to support human well-being and alleviate environmental degradation at the same time, it should not matter whether the economy grows or diminishes. Positioning economic growth as a constituent of sustainable development unnecessarily and counterproductively narrows down the selection of means by which sustainability is pursued'. Therefore, the low mention rate of economic growth among the participating pre-service teachers could reflect the negative impression that it is a negative thing if not connected with positive results for the environment and humankind.

\subsection{Pre-Service Teachers' Perceptions about Sustainable Development}

The low self-evaluation of the pre-service teachers could reproduce the fact that most of them had never environmental education or ESD training during their formal education and their studies. This is rather understandable since EE or ESD is not part of the curriculum in Greece, but it is usually part of informal education. Interested teachers and groups of students can participate in environmental projects throughout the schooljear on a voluntary basis. Environmental Centers, which are structures formed by the Ministry of Education offer support to the interested teachers and additionally environmental networks among the environmenta center and participating schools on spccific projects, as for example recycling and reuse, clean water, the routs of water, etc. In addition, a resent study of Greek university departments conducted by Chita et al. (2016) found that the percentage of courses related to sustainability and the environment is higher at the postgraduate level compared to undergraduate study programmes, while university departments that focus on education, pre-school or primary, offer a surprisingly high number of courses related to sustainability and the environment. Since our study was conducted at a pre-school university department, the participating students, who were mostly during their $7^{\text {th }}$ or $8^{\text {th }}$ semester, might not have have these courses yet. Furthermore, the low self-evaluation of their knowledge of EE or ESD could also be because of their propper understanding of the complex and multifaceted nature of ESD (Bursjöö 2011; Cotton, Warren, Maiboroda \& Bailey 2007; Fien \& Tilbury 2002; Huckle 1996; McKeown, 2002; O'Riordan \& Voisey, 1998). This also might be the reason why the vast majority feel that they need further training on ESD and that this would improve their ability to teach their students, while they also support the inclusion of ESD in teacher education university departments.

Although they seem to comprehend the difficulties of ESD the clear majority believe that they, as teachers can make a difference and help through education prepare democratic citizens, able to solve environmental problems. In the of the UNESCO (2002) report on the lessons learnt about the contribution of ESD over the decade between the United Nations Conference on Environment and Development in 1992 and the World Summit on Sustainable Development (WSSD) the quote from the Earth Summit in Rio de Janiero in 1992 is reminded, that educators around the world must reorient education 'to once again reflect such a vision of sustainability, one that links economic well-being with cultural traditions and respect for Earth and its resources'. The pre-service teachers could be aware that teachers need to contribute in order to facilitate students to gain knowledge, positive attitudes and appropriate skills (Birdsall, 2010) and to face the major problems of our time. 


\subsection{Attitudes towards SD and ESD}

Very few pre-service teachers state that they take actions towards SD issues, although the majority supports the statement that it is a good thing. Although, Gayford \& Dillon (1995) argue that for environmental issues, there is not a clear, linear relationship between knowledge, understanding and behavioural change. Furthremore, Dillon \& Gayford (1997) recognize that student teachers' green attitudes 'cannot be treated as though they arise from a common, shared base, but rather that the range of influences on the public in general are likely to be reflected within this sub-group'. Manning (2009) engages social norms to explain people's sustainability actions: 'Social norms are the implicit social rules that govern behavior within a community. Norms are not directly established, instead, they develop over time as people go about their daily behaviors, sense people's reactions to those behaviors, and observe what other people are doing. Social norms differ depending on the group of people, community, or culture. What is considered fully normal, even admirable, in one group may be met with disapproval in another'. This view is also supported by Cialdini (2005), who found that people need social approvement to guide their behavior. Obviously one of the big challenges we face in creating a sustainable culture is the fact that so many unsustainable actions are considered perfectly normal (Manning, 2009), while sustainable behaviors are often seen as lower status and undesirable (Sadalla \& Krull, 1995).

Our findings show that although most pre-service students think that a sustainable behavior is a good thing, considering it important both for their teachings and their personal stance in life, they rather donnot take action either because of lack of knowledge about what to do, or as part of being under societal obligation to a specific behavioral attitude. They state however, that they are willing to include ESD in their teachings, but therefore they feel that they need appropriate training for that, and therefore the clear majority of the pre-service teachers stated that it is important to include ESD in teacher education university departments. Including ESD into the curricula would therefore directly impact their ability to teach about SD. They also support the view that it is important to start teaching about the environment at the early childhood education level. But the majority of the participating pre-service teachers agreed that they need further education on sustainability issues.

\subsection{Appropriate Teaching Approaches for ESD}

Most pre-service teachers are aware that ESD needs specific teaching approaches in accordance with previous findings from literature, namely learner-centred, action-oriented and transformativeactive (Rieckmann, 2014). These participatory teaching and learning methods empower learners to take action to promote sustainable development.

Interdisciplinary work was rated very low as a preferred teaching method by the pre-service teachers, although it is a highly recommended approach by many scholars, bearing many advantages for ESD. This could be due to the nature of their specific studies, as Early Childhood teachers get a spheric rather but not in-depth education, equipping them in an interdiciplinary way. Another explanation could be that in secondary school teachers of all disciplines are available for interdisciplinary work, but such a coopration is rather difficult in an Early Childhood classroom.

\section{Conclusions}

The participating pre-service teachers are from various places from Greece, displaying an average sample of the Early Childhood pre-service teachers, thus their former knowledge in generizable, although specific university departments may cover SD issues in different ways, offering more specialized classes, which is the case for 2 out of 6 Early Childhood Departments. In 2 university departments ESD is offered in connection with Environmental Education, and the other 2 departments do not mention ESD in their curricula.

Our study about the knowledge, perceptions and attitudes of Early Childhood pre-service teachers shows that they lack knowledge, having an unclear perception of what it is about. They understand the environmental dimension of SD quite well but are uncertain about societal and financial issues. Nevertheless, they feel that sustainability is an important issue and therefore, they need training on ESD, which would influence their ability to teach their students. They have a positive stance on teaching ESD in their classrooms and state the ESD should be taught starting from the Early Childhood education level. They also hold the belief that teachers can influence through their teachings to help solve environmental problems. To prepare pre-service teachers for their difficult job of cultivating critically thinking democratic citizens, they need support with proper education and training during their studies and in the future with professional development trainings. This is possible by the collaboration of primary and secondary teachers with universities since ESD is an ongoing subject and not a set of knowledge which must or even can be learned. 


\section{References}

Adawiah, J., \& Norizan, E. (2012). Teachers' knowledge of education for sustainable development. UMT 11th International Annual Symposium on Sustainability Science and Management, Terengganu, Malaysia. Retrieved from https://www.researchgate.net/publication/263011209_Teachers'_Knowledge_of_Education_for_Sustainable_De velopment

Bandura, A. (1977). Self-efficacy: Toward a Unifying Theory of Behavioral Change. Psychological Review, 84(2), 191-215. https://doi.org/10.1037//0033-295X.84.2.191

Bandura, A. (2005). Guide for Constructing Self-Efficacy Scales. In F. Pajares, \& T. Urdan (Eds.), Self-efficacy Beliefs of Adolescents (pp. 307-337). Greenwich, Connecticut: Information Age Publishing.

Biasutti, M. (2015). An intensive programme on education for sustainable development: the participants' experience. Environmental Education Research, 21(5), 734-752. https://doi.org/10.1080/13504622.2014.921805.

Biasutti, M., \& Frate, S. (2017). A validity and reliability study of the Attitudes toward Sustainable Development scale. Environmental Education Research, 23(2), 214-230. https://doi.org/10.1080/13504622.2016.1146660

Birdsall, S. (2010). Empowering Students to Act: Learning About, Through and From the Nature of Action. Australian Journal of Environmental Education, 26, 65-84. https://doi.org/10.1017/S0814062600000835

Bonnett, M. (2003). Metaphysics, Education and Environmental Concern. Journal of Philosophy of Education, 37(4), 564-575. https://doi.org/10.1111/j.0309-8249.2003.00348.x

Borg, C., Gericke, N., Höglund, H.-O., \& Bergman, E. (2014). Subject- and experience-bound differences in teachers' conceptual understanding of sustainable development. Environmental Education Research, 20(4), 526-551, https://doi.org/10.1080/13504622.2013.833584

Boström, M., Casula Vifell, Å., Klintman, M., Soneryd, L., Tamm Hallström, K., \& Thedvall, R. (2015). Social Sustainability Requires Social Sustainability: Procedural Prerequisites for Reaching Substantive Goals. Nature and Culture, 10(2), 131-156. https://doi.org/10.3167/nc.2015.100201

Bursjöö, I. (2011). How student teachers form their educational practice in relation to sustainable development. Utbilding \& Demokrati, 20(1), 59-78.

Caiman, C., \& Lundegård, I. (2014). Pre-school children's agency in learning for sustainable development. Environmental Education Research, 20(4), 437-459. https://doi.org/10.1080/13504622.2013.812722

Chita, E., Kameas, A., Kornelaki, A. C., Plakitsi, K., Kolios, V., \& Maidou, A. (2016). Identifying the gap in courses on sustainable development offered by Greek universities. In J. Lavonen, K. Juuti, J. Lampiselkä, A. Uitto \& K. Hahl (Eds.), Electronic Proceedings of the ESERA 2015 Conference. Science education research: Engaging learners for a sustainable future, Part 9 (co-ed. M. Achiam \& G. Carvalho), (pp. 1389-1400). Helsinki, Finland: University of Helsinki. ISBN 978-951-51-1541-6.

Christie, B. A., Miller, K. K., Cooke, R., \& White, J. G. (2013). Environmental sustainability in higher education: how do academics teach? Environmental Education Research, 19(3), 385-414. https://doi.org/10.1080/13504622.2012.698598

Chunteng, L. (2004). Survey of primary and secondary school teachers' teaching competence for environmental education in Xicheng District of Beijing. Chinese Education \& Society, 37(4), 39-44.

Cialdini, R. (2005). Basic social influence is underestimated. Psychological inquiry, 16(4), 158-161. https://doi.org/10.1207/s15327965pli1604_03

Colantonio, A., \& Dixon, T. (2009). Measuring Socially Sustainable Urban Regeneration in Europe. Oxford, UK: Oxford Institute for Sustainable Development.

Cordina, M., \& Mifsud, M. C. (2016). A Quantitative Study of Maltese Primary School Teachers and Their Perceptions Towards Education for Sustainable Development. US-China Education Review B, 6(6), 329-349. https://doi.org/10.17265/2161-6248/2016.06.001

Corney, G. (2006). Education for Sustainable Development: An Empirical Study of the Tensions and Challenges Faced by Geography Student Teachers. International Research in Geographical and Environmental Education, 15(3), 224-240. https://doi.org/10.2167/irgee194.0

Corney, G., \& Reid, A. (2007). Student Teachers' Learning about Subject Matter and Pedagogy in Education for 
Sustainable Development. Environmental Education Research, 13(1), 33-54. https://doi.org/10.1080/13504620601122632

Cotton, D. R. E., Bailey, I., Warren, M., \& Bissell, S. (2009). Revolutions and second-best solutions: Education for Sustainable Development in Higher Education. Studies in Higher Education, 34(7), 719-733. https://doi.org/10.1080/03075070802641552

Cotton, D. R. E., Warren, M. F., Maiboroda, O., \& Bailey, I. (2007). Sustainable development, higher education and pedagogy: a study of lecturers' beliefs and attitudes. Environmental Education Research, 13(5), 579-597. https://doi.org/10.1080/13504620701659061.

Cotton, D. R. E., \& Winter, J. (2010). It's not just Bits of Paper and Light Bulbs: A review of Sustainability Pedagogies and their Potential for use in Higher Education. In Jones, P., Selby, D. and Sterling, S. (Eds.), Sustainability Education: Perspectives and Practice Across Higher Education. London, UK: Earthscan. https://doi.org/10.1080/13504620701659061

Cuthill, M. (2010). Strengthening the 'Social' in Sustainable Development: Developing a Conceptual Framework for Social Sustainability in a Rapid Urban Growth Region in Australia. Sustainable Development, 18, 362-373. https://doi.org/10.1002/sd.397

Cutter-Mackenzie, A., \& Smith, R. (2003). Ecological literacy: The "missing paradigm" in environmental education (part one). Environmental Education Research, 9(4), 497-524. https://doi.org/10.1080/1350462032000126131

Dempsey, N., Bramley, G., Power, S., \& Brown, C. (2011). The Social Dimension of Sustainable Development: Defining Urban Social Sustainability. Sustainable Development, 19, 289-300. https://doi.org/10.1002/sd.417

Dillon, P. J., \& Gayford, C. G. (1997). A Psychometric Approach to Investigating the Environmental Beliefs, Intentions and Behaviours of Pre - service Teachers. Environmental Education Research, 3(3), 283-297. https://doi.org/10.1080/1350462970030303

Duhn, I. (2012). Making 'place' for Ecological Sustainability in Early Childhood Education. Environmental Education Research, 18(1), 19-29. https://doi.org/10.1080/13504622.2011.572162

Economic Commission for Europe Committee (ECEC) (2005). On Environmental Policy, High-level meeting of Environment and Education Ministries (Vilnius, 17-18 March 2005). (Agenda items 5 and 6) UNECE Strategy for Education For Sustainable Development, adopted at the High-level meeting. Retrieved from https://www.unece.org/trans/main/dgdb/dgsubc4/c42005.html.

Fien, J., \& Tilbury, D. (2002). The global challenge of sustainability. In D. Tilbury, R. B. Stevenson, J. Fien \& D. Schreuder (Eds.), Education and Sustainability: Responding to the Global Challenge (pp. 1-12). Gland, Switzerland and Cambridge, UK: IUCN.

Firth, R., \& Winter, C. (2007). Constructing education for sustainable development: the secondary school geography curriculum and initial teacher training. Environmental Education Research, 13(5), 599-619. https://doi.org/10.1080/13504620701659079

Gan, D., \& Gal, A. (2018). Self-efficacy for promoting EfS among pre-service teachers in Israel. Environmental Education Research, 24(7), 1062-1075. https://doi.org/10.1080/13504622.2017.1396288

Garrard, G. (2010). Problems and Prospects in Ecocritical Pedagogy. Environmental Education Research, 16(2), 233-245. https://doi.org/10.1080/13504621003624704

Gayford, C. G., \& Dillon, P. J. (1995). Policy and the practice of environmental education in England: a dilemma for teachers. Environmental Education Research, 1, 173-184. https://doi.org/10.1080/1350462950010204

Green, B. (2004). Personal construct psychology and content analysis. Personal Construct Theory \& Practice, 1, 82-91.

Haapanen, L., \& Tapio, P. (2016). The role of economic growth in sustainable development from the perspective of 21st century growth critique. Retrieved from https://sustainabledevelopment.un.org/content/documents/1007751_Haapanen\%20et\%20al._The\%20role\%20of $\% 20$ economic $\% 20$ growth $\% 20 \mathrm{in} \% 20$ sustainable $\% 20$ development $\% 20$ from $\% 20$ the $\% 20$ perspective $\% 20$ of $\% 2021$ st $\% 20$ century\%20growth\%20critique.pdf

Haney, J. J., Lumpe, A. T., Czerniak, C. M., \& Egan, V. (2002). From Beliefs to Actions: The Beliefs and Actions of Teachers Implementing Change. Journal of Science Teacher Education, 13(3), 171-187. 
https://doi.org/10.1023/A:1016565016116

Hart, P., \& Nolan, K. (1999). A critical analysis of research in environmental education. Studies in Science Education, 34(1), 1-69. https://doi.org/10.1080/03057269908560148

Hopkins, C., \& McKeown, R. (2005). Guidelines and recommendations for reorienting teacher education to address sustainability. Education for Sustainable Development in Action Technical Paper, (2). Paris, France: UNESCO.

Jenson, B. B., \& Schnack, K. (1997). The action competence approach in environmental education. Environmental Education Research, 3(2), 163-78. https://doi.org/10.1080/1350462970030205

Johnsson-Latham, G. (2007). A study on gender equality as a prerequisite for sustainable development. Stockholm, Sweden: The Environment Advisory Council Ministry of the Environment.

Jucker, R. (2002). Our common illiteracy: Education as if the Earth and people mattered. Frankfurt am Main: Peter Laing.

Karpudewan, M., Ismail, Z., \& Roth, W.-M. (2012). Promoting pro-environmental attitudes and reported behaviors of Malaysian pre-service teachers using green chemistry experiments. Environmental Education Research, 18(3), 375-389, https://doi.org/10.1080/13504622.2011.622841

Manning, C. (2009). The Psychology of Sustainable Behavior. Tips for empowering people to take environmentally positive action. Minnesota, US: Minnesota Pollution Control Agency.

McKeown, R. (2002). Education for sustainable development toolkit. Retrieved from http://www.esdtoolkit.org/

McKeown, R. (2014). The Leading Edge of Teacher Education and ESD. Journal of Education for Sustainable Development, 8(2), 127-131. https://doi.org/10.1177/0973408214548366

McKeown, R., \& Hopkins, C. (2003). EE $\neq$ ESD: Defusing the worry. Environmental Educational Research, 9(1), 117-128. https://doi.org/10.1080/13504620303469

McNaughton, M. J. (2012). Implementing Education for Sustainable Development in Schools: Learning from Teachers' Reflections. Environmental Education Research, 18(6), 765-782. https://doi.org/10.1080/13504622.2012.665850

Milner, A. R., Sondergerd, T. A., Demir, A., Johnson, C. C., \& Czerniak, C. M. (2012). Elementary Teachers' Beliefs About Teaching Science and Classroom Practice: An Examination of Pre/Post NCLB Testing in Science. Journal of Science Teacher Education, 23(2), 111-132. https://doi.org/10.1007/s10972-011-9230-7

Kennelly, J., Taylor, N., \& Maxwell, T. (2008a). A Student Teacher's Personal Pathway to Education for Sustainability. Australian Journal of Environmental Education, 24, 23-33. https://doi.org/10.1017/S0814062600000550

Kennelly, J., Taylor, N., \& Maxwell, T. (2008b). Addressing the Challenge of Preparing Australian Pre-service Primary Teachers in Environmental Education: An Evaluation of a Dedicated Unit. Journal of Education for Sustainable Development, 2(2), 141-156. https://doi.org/10.1177/097340820800200211

Lysgaard, J. A., \& Simovska, V. (2016). The significance of 'participation' as an educational ideal in education for sustainable development and health education in schools. Environmental Education Research, 22(5), 613-630. https://doi.org/10.1080/13504622.2015.1029875

Malandrakis, G. (2018). Influencing Greek pre-service teachers' efficacy beliefs and self-confidence to implement the new 'Studies for the Environment' curricula. Environmental Education Research, 24(4), 537-563. https://doi.org/10.1080/13504622.2016.1272672

Morgensen, F., \& Schnack, K. (2010). The action competence approach and the 'new' discourses of education for sustainable development, competence and quality criteria. Environmental Education Research, 16(1), 59-74. https://doi.org/10.1080/13504620903504032

O’Riordan, T. (1981). Environmentalism and education. Journal of Geography in Higher Education, 5(1), 3-17. https://doi.org/10.1080/03098268108708785

O'Riordan, T., \& Voisey, H. (1998). The Transition to Sustainability: The Politics of Agenda 21. London: Earthscan.

Pepper, C., \& Wildy, H. (2008). Leading for Sustainability: Is Surface Understanding Enough?. Journal of Educational Administration, 46(5), 613-629. https://doi.org/10.1108/09578230810895528

Plakitsi, K., Kolokouri, E., Nanni, E., Stamoulis E., \& Theodoraki, X. (2013). Chat in Developing New 
Environmental Science Curricula, School Textbooks, and Web-Based Applications for the First Grades. In K. Plakitsi (Ed.), Activity theory in formal and informal education (pp.83-110). The Netherlands: Sense Publishers. https://doi.org/10.1007/978-94-6091-317-4_5

Price, C. (2010). Sowing the Seed: Education for Sustainability within the Early Years Curriculum. European Early Childhood Education Research Journal, 18(3), 423-432. https://doi.org/10.1080/1350293X.2010.500082

Reid, A., Jensen, B. B., Nikel, J., \& Simovska, V. (2008). Participation and Learning. Perspectives on Education and the Environment, Health and Sustainability. Netherlands: Springer. https://doi.org/10.1007/978-1-4020-6416-6

Rieckmann, M. (2018). Learning to transform the world: key competencies in Education for Sustainable Development. In A. Leicht, J. Heiss and W. J. Byun (Eds.), Issues and trends in Education for Sustainable Development. Paris, France: UNESCO.

Roth, W.-M., Goulart, M. I. M., \& Plakitsi, K. (2013). Science Education during Preschool Years. A Cultural-Historical Approach. Dordrecht: Springer. https://doi.org/10.1007/978-94-007-5186-6

Sadalla, E., \& Krull, J. (1995). Self-presentational barriers to resource conservation. Environment and Behavior, 27, 328-353. https://doi.org/10.1177/0013916595273004

Saka, A., \& Sahintürk, A. (2013). Attitudes of prospective forest engineers and primary school teachers towards a sustainable environment. Polish Journal of Environmental Studies, 22(50), 1533-1557.

Scott, W. A. H. (2005). ESD: What Sort of Decade? What Sort of Learning? Keynote Address at the UK Launch of the UNESCO Decade for ESD. Bath: University of Bath.

Scott, W. A. H., \& Gough, S. (2003). Sustainable development and learning: framing the issues. London, UK: Routledge/Falmer. https://doi.org/10.4324/9780203464625

Shapiro, B. L. (1991). The use of personal construct theory and the repertory grid in the development of case studies of children's science learning. International Journal of Personal Construct Psychology, 4, 251-271. https://doi.org/10.1080/08936039108406118

Shephard, K. (2008). Higher Education for Sustainability: Seeking Affective Learning Outcomes. International Journal of Sustainability in Higher Education, 9(1), 87-98. https://doi.org/10.1108/14676370810842201

Sterling, S. (2010). Learning for resilience or the resilient learner? Towards a necessary reconciliation in a paradigm of sustainable education. Environmental Education Research, 16(5), 511-528. https://doi.org/10.1080/13504622.2010.505427

Sterling, S. (2011). Transformative learning and sustainability: sketching the conceptual ground. Learning and Teaching in Higher Education, 5, 17-33.

Stevenson, R. B. (2007). Schooling and Environmental/Sustainability Education: From Discourses of Policy and Practice to Discourses of Professional Learning. Environmental Education Research, 13(2), 265-285. https://doi.org/10.1080/13504620701295650

Summers, M., \& Childs, A. (2007). Student Science Teachers' Conceptions of Sustainable Development: An Empirical Study of Three Postgraduate Training Cohorts. Research in Science \& Technological Education, 25(3), 307-327. https://doi.org/10.1080/02635140701535067

Summers, M., Childs, A., \& Corney, G. (2005). Education for Sustainable Development in Initial Teacher Training: Issues for Interdisciplinary Collaboration. Environmental Education Research, 11(5), 623-647. https://doi.org/10.1080/13504620500169841

Summers, M., Corney, G., \& Childs, A. (2003). Teaching Sustainable Development in Primary Schools: An Empirical Study of Issues for Teachers. Environmental Education Research, 9(3), 327-346. https://doi.org/10.1080/13504620303458

Summers, M., Corney, G., \& Childs, A. (2004). Student Teacher's Conceptions of Sustainable Development: The Starting Points of Geographers and Scientists. Educational Research, 46(2), 163-182. https://doi.org/10.1080/0013188042000222449

Sund, P., \& Wickman, P.-O. (2008). Teachers' Objects of Responsibility: Something to care about in education for sustainable development?. Environmental Education Research, 14(2), 145-163. https://doi.org/10.1080/13504620801951681 
Symons, G. (2008). Practice, Barriers and Enablers in ESD and EE: A Review of the Research. Shrewsbury: SEEd.

Tomas, L., Girgenti, S., \& Jackson, C. (2017). Pre-service teachers' attitudes toward education for sustainability and its relevance to their learning: implications for pedagogical practice. Environmental Education Research, 23(3), 324-347. https://doi.org/10.1080/13504622.2015.1109065

Tschannen-Moran, M., Hoy, A. W., \& Hoy, W. K. (1998). Teacher Efficacy: Its Meaning and Measure. Review of Educational Research, 68(2), 202-248. https://doi.org/10.3102/00346543068002202

Tuncer, G., Tekkaya C., Sungur, S., Cakiroglu, J., Ertepinar, H., \& Kaplowitz, M. (2009). Assessing pre-service teachers' environmental literacy in Turkey as a mean to develop teacher education programs. International Journal of Educational Development, 29, 426-436. https://doi.org/10.1016/j.ijedudev.2008.10.003

UNESCO. (1992). United Nations Conference on Environment and Development: Agenda 21. UNESCO: Switzerland.

UNESCO. (2002). Education for Sustainability from Rio to Johannesburg: Lessons learnt from a decade of commitment. Paris, France: UNESCO.

UNESCO. (2004). United Nations Decade of Education for Sustainable Development 2005-2014. Draft Implementation Scheme. Retrieved from http://portal.unesco.org/education/en/filedownload.php/03f375b07798a2a55dcdc39db7aa8211Final+IIS.pdf

UNESCO. (2005). Guidelines and Recommendations for Reorienting Teacher Education to Address Sustainability. Paris: UNESCO.

UNESCO. (2005b). United Nations Decade of Education for Sustainable Development: Draft International Implementation Scheme. Paris: UNESCO.

UNESCO. (2009). Review of Contexts and Structures for the Education for Sustainable development 2009. Division for the Coordination of United Nations Priorities in Education, Paris: UNESCO.

UNESCO. (2012). Education for Sustainable Development in Action. Paris: UNESCO.

United Nations Educational, Scientific and Cultural Organization (UNESCO) (2014). Results from ESD UNESCO Questionnaire 2: Input from online survey for Member States, Key Stakeholders and UN Agencies. Paris: UNESCO.

UNESCO. (2016). Education 2030 Incheon Declaration. Towards inclusive and equitable quality education and lifelong learning for all. ED-2016/WS/28.

United Nations (2019). Goal 5: Achieve gender equality and empower all women and girls. Retrieved from https://www.un.org/sustainabledevelopment/gender-equality/

Wals, A. E. J., \& Jickling, B. (2002). 'Sustainability' in higher education: From doublethink and newspeak to critical thinking and meaningful learning. International Journal of Sustainability in Higher Education, 3, 221-232. https://doi.org/10.1108/14676370210434688

Winter, C., \& Firth, R. (2007). Knowledge about Education for Sustainable Development: four case studies of student teachers in English secondary schools. Journal of Education for Teaching, 33(3), 341-385. https://doi.org/10.1080/02607470701450528

World Commission on Environment and Development (WCED). (1987). Our Common Future. New York, NY: United Nations.

Yavetz, B., Goldman, D., \& Pe'er, S. (2009). Environmental Literacy of Pre-service Teachers in Israel: A Comparison between Students at the Onset and End of Their Studies. Environmental Education Research, 15(4), 393-415. https://doi.org/10.1080/13504620902928422 